\title{
A tüdőmetastasisok sebészi kezelésében történt változások az elmúlt 12 évben
}

\author{
Németh Tibor dr. ${ }^{1}$ - Szabó Zsolt dr. ${ }^{2}$ - Pécsy Balázs dr. ${ }^{1}$ \\ Barta Zsanett Virág dr. ${ }^{1}$ - Lázár György dr. ${ }^{1}$ - Torday László dr. ${ }^{3}$ \\ Maráz Anikó dr. ${ }^{3}$ - Zombori Tamás dr. ${ }^{4}$ - Furák József dr. ${ }^{1}$ \\ ${ }^{1}$ Szegedi Tudományegyetem, Általános Orvostudományi Kar, Sebészeti Klinika, Szeged \\ ${ }^{2}$ Szegedi Tudományegyetem, Általános Orvostudományi Kar, \\ Aneszteziológiai és Intenzív Terápiás Intézet, Szeged \\ ${ }^{3}$ Szegedi Tudományegyetem, Általános Orvostudományi Kar, Onkoterápiás Klinika, Szeged \\ ${ }^{4}$ Szegedi Tudományegyetem, Általános Orvostudományi Kar, Patológiai Intézet, Szeged
}

\begin{abstract}
Bevezetés: Retrospektív munkánkban az elmúlt 12 év alatti két, 5 éves időszakban vizsgáltuk a tüdőmetastasisok szövettan szerinti megoszlásában és a metastasectomiák típusában végbement változásokat.

Célkitüzés és módszer: Az első csoportban (2006-2010) 55 beteg volt: férfi 54,5\% ( $\mathrm{n}=30)$, nő 45,5\% ( $\mathrm{n}=25)$, átlagos életkor 57,9 év (24-80); a második csoportban (2014-2018) 115 beteg volt: férfi 60\% ( $\mathrm{n}=69)$, nő $40 \%(\mathrm{n}=46)$, átlagos életkor 62,2 év (26-82).

Eredmények: Az elsó időszakban a rectumban 19,3\%-ban $(\mathrm{n}=11)$, a colonban 17,5\%-ban $(\mathrm{n}=10)$, a vesében 14\%ban $(\mathrm{n}=8)$ volt a primer tumor, a második periódusban a colonban $23,1 \%$-ban $(\mathrm{n}=31)$, a rectumban $15,7 \%$-ban $(\mathrm{n}=21)$, a vesében 9\%-ban $(\mathrm{n}=12)$. A mútétek megoszlása: atípusos reszekció: $38,6 \%(\mathrm{n}=22)$ és $46,3 \%(\mathrm{n}=62)$; lobectomia $31,6 \%(\mathrm{n}=18)$ és $26,9 \%(\mathrm{n}=36)$; pulmonectomia $10,5 \%(\mathrm{n}=6)$ és $1,5 \%(\mathrm{n}=2)$; segmentectomia $7 \%$ $(\mathrm{n}=4)$ és $9,7 \%(\mathrm{n}=13)$; bilobectomia $1,8 \%(\mathrm{n}=1)$ és $0,7 \%(\mathrm{n}=1)$ az első és a második csoportban, egyenként. Az elsó periódusban végzett 'video-assisted thoracic surgery' (VATS) mútétek aránya 5,3\%-ról $(\mathrm{n}=3)$ a második periódusban $64,9 \%$-ra $(\mathrm{n}=87)$ növekedett. A primer tumor mútéte és a tüdőáttét eltávolítása közötti betegségmentes időszak az első csoportban átlagosan 45,2 hónap (0-144), a másodikban átlagosan 33,8 hónap (0-180) volt. Az első periódusban észlelt 39 hónapos medián túlélés a második csoportban 59 hónapra emelkedett. Az átlagos 5 éves túlélés mindkét csoportunkban $41 \%$ volt.

Következtetés: Az elmúlt 12 év alatt a tüdóattétek eltávolításán átesett betegek száma a kétszeresnél is jobban megemelkedett, és jelentősen nőtt a VATS-metastasectomia aránya (5,3\% vs. 64,9\%). A primer tumoros megoszlásban nem találtunk jelentős eltérést. A medián túlélés a második csoportban némileg jobbnak bizonyult.

Orv Hetil. 2020; 161(29): 1215-1220.
\end{abstract}

Kulcsszavak: tüdőmetastasis, thoracotomia, VATS

\section{Changes in the surgical treatment of pulmonary metastases during the last 12 years}

\begin{abstract}
Introduction: In our retrospective study, we examined changes in the histological results and types of metastatectomies of pulmonary metastases during the last 12 years, in two 5 -year periods.

Aim and method: There were 55 patients in the first group (2006-2010), 54.5\% of the patients were male $(\mathrm{n}=30)$, $45.5 \%$ were female $(\mathrm{n}=25)$, the mean age was 57.9 years $(24-80)$. The second group (2014-2018) consisted of 115 patients, with $60 \%$ male $(\mathrm{n}=69)$ and $40 \%$ female $(\mathrm{n}=46)$, the mean age was 62.2 years $(26-82)$.

Results: During the first period, the primary tumor was found in the rectum $19.3 \%(\mathrm{n}=11)$, colon $17.5 \%(\mathrm{n}=10)$, or kidney $14 \%(n=8)$, while during the second period, the primary tumor was in the colon in $23.1 \%(n=31)$, in the rectum in $15.7 \%(n=21)$, or in the kidney in $9 \%(n=12)$. The following types of surgeries were performed: atypical resection: $38.6 \%(n=22)$ and $46.3 \%(n=62)$; lobectomy in $31.6 \%(n=18)$ and $26.9 \%(n=36)$; pulmonectomy in $10.5 \%(\mathrm{n}=6)$ and $1.5 \%(\mathrm{n}=2)$; segmentectomy in $7 \%(\mathrm{n}=4)$ and $9.7 \%(\mathrm{n}=13)$; and bilobectomy in $1.8 \%(\mathrm{n}=1)$ and $0.7 \%(\mathrm{n}=1)$ in the first and second group, respectively. The ratio of video-assisted thoracic surgery (VATS) was $5.3 \%(\mathrm{n}=3)$ during the first period, and this ratio increased to $64.9 \%(\mathrm{n}=87)$ during the second period. The mean disease-free survival between the surgery of the primary tumor and the removal of the pulmonary metastasis was 45.2
\end{abstract}


months (0-144) during the first period and 33.8 months (0-180) during the second period. The median survival was 39 months in the first period, and it increased to 59 months in the second group. The mean 5 -year survival was $41 \%$ in both groups.

Conclusion: During the last 12 years, there was a more than two-fold increase in the number of patients requiring surgery due to pulmonary metastases, and the ratio of VATS metastasectomy increased significantly as well $(5.3 \%$ vs. $64.9 \%)$. No significant difference was found in the ratio of the types of the primary tumors. The median survival was slightly better in the second group.

Keywords: pulmonary metastasis, thoracotomy, VATS

Németh T, Szabó Zs, Pécsy B, Barta ZsV, Lázár Gy, Torday L, Maráz A, Zombori T, Furák J. [Changes in the surgical treatment of pulmonary metastases during the last 12 years]. Orv Hetil; 161(29): 1215-1220.

(Beérkezett: 2020. február 29; elfogadva: 2020. március 25.)

\begin{abstract}
Rövidítések
$\mathrm{CEA}=$ carcinoembryonalis antigén; $\mathrm{CRC}=$ colorectalis carcinoma; $\mathrm{CT}=$ (computer tomography) számítógépes tomográfia; $\mathrm{DFI}=($ disease-free interval) betegségmentes időköz; ENB = elektromágneses navigációs bronchoszkópia; ESTS = (European Society of Thoracic Surgeons) Mellkassebészek Európai Társasága; NITS $=($ non-intubated thoracic surgery $)$ nem intubált mellkasi mútét; PET/CT = pozitronemissziós tomográfiával kombinált komputertomográfia; SPSS $=($ Statistical Package for the Social Sciences) társadalomtudományi statisztikai csomag; SUV = (standard uptake value) standard felvételi érték; VATS = (video-assisted thoracic surgery) videoasszisztált mellkasi mútét
\end{abstract}

Az áttétek jelentőségét az adja, hogy a daganatos betegek halálozásának 90\%-áért a metastasisok felelősek [1]. Tüdőmetastasisok esetén, amennyiben az a reszekabilitás kritériumainak megfelel, az épben történő, azaz a mikroszkópos és makroszkópos tumor hátrahagyása nélküli mútéti eltávolítás [2] a betegek teljes daganatmentességét, hosszú távú túlélését eredményezheti. A Korányi Évkönyv adatai szerint 2013-ban 316 reszekció történt Magyarországon tüdő́ttét indikációjával, ezek közül 107 VATS-technikával került elvégzésre [3]. Az ESTStagok önkéntes adatszolgáltatására épülő ESTS Database adatközlése szerint 2015-ben a tüdőreszekciók 14,2\%-a $(\mathrm{n}=8891)$ történt másodlagos rosszindulatú tüdőfolyamatok miatt, és az összes tüdőreszekció 21,7\%-a történt VATS-módszerrel [4].

Retrospektíven vizsgáltuk a 2006 és 2018 között tüdő-metastasectomián átesett betegeket, $\mathrm{s}$ ennek során két, 5 éves időszakra eső mütétek jellemzőit értékeltük. Azt vizsgáltuk, hogy a viszonylag távol eső időszakaszokban milyen változások jöttek létre a tumor jellemzói és mútéti megoldásai terén.

\section{Betegek és módszer}

A betegeket két csoportba osztottuk. Az első csoportba 2006 és 2010 között, a második csoportba 2014 és 2018 között mútött betegek kerültek. Az első csoportban 55 betegnél végeztünk 57 mû́tétet. Első metastasis-eltávolításon a betegek $94,7 \%$-a $(\mathrm{n}=54)$, ismételt metastasiseltávolításon a betegek $6,3 \%-\mathrm{a}(\mathrm{n}=3)$ esett át. A betegek $54,5 \%$-a $(\mathrm{n}=30)$ férfi, $45,5 \%$-a $(\mathrm{n}=25)$ nő, az átlagos életkor 57,9 év (24-80 év) volt. A második csoportban 115 beteg, 69 férfi $(60 \%)$ és 46 nő (40\%) volt, átlagos életkoruk 62,2 év (26-82 év). Ezen időszak alatt a mútétek $85,1 \%$-át $(\mathrm{n}=114)$ az első metastasis eltávolítása, míg $14,9 \%$-át $(\mathrm{n}=20)$ az ismételt metastasectomia tette ki.

A mútét elötti kivizsgálás részeként megtörténik a mellkasi CT-vizsgálat, bronchoszkópia, pletizmográfiás vizsgálat. A mútét elótti elhúzódó 'staging' vizsgálatokat az utóbbi időben PET/CT vizsgálattal válthatjuk ki.

A mútétek elvégzéséhez 2 lumenú, izolált tubussal intubáljuk a betegeket. NITS mûtétek esetén a betegek nincsenek intubálva és relaxálva. A betegek oldalfekvésben helyezkednek el a mútőasztalon. A posterolateralis thoracotomiából elvégzett reszekciók a következők: segmentectomia, lobectomia, pulmonectomia, illetve atípusos reszekció. A mútét végén 1 vagy 2 mellkasi drén és 1 subpleuralis fájdalomcsillapító kanül hátrahagyása után rétegesen zárjuk a thoracotomia sebét. VATS mútét esetén 1 vagy több metszésből történik a feltárás, majd a reszekció kiterjedése megegyezik a nyitott mûtétnél jelzettel.

A statisztikai analízist az SPSS v. 15-ös programmal, Kaplan-Meier-metódussal végeztük (IBM ${ }^{\circledast}$, Armonk, NY, Amerikai Egyesült Államok).

\section{Eredmények}

A primer tumor lokalizációjának megoszlását vizsgálva azt láthatjuk, hogy mindkét periódusban a colorectalis daganatok adtak a leggyakrabban tüdőáttétet ( $36,8 \%$ vs. $38,8 \%)$, ezt követte a vese- ( $14 \%$ vs. $9 \%)$, majd a bôr melanoma malignum ( $14 \%$ vs. $7,5 \%)$ eredet. A részletes adatokat az 1. táblázatban foglaltuk össze. A 2. táblázat a két vagy több ülésben végzett, ismételt metastasectomián átesetteknél összegzi a primer tumor helyét. 
A primer tumor kiindulási helye szerinti megoszlás az együléses, egy- vagy kétoldali metastasectomián átesett betegek között, mindkét vizsgált periódusban

\begin{tabular}{|c|c|c|}
\hline A primer tumor helye & $\begin{array}{c}2006-2010 \\
(\mathrm{n}=54)\end{array}$ & $\begin{array}{c}2014-2018 \\
(\mathrm{n}=114)\end{array}$ \\
\hline Colon & $10(17,5 \%)$ & $31(23,1 \%)$ \\
\hline Rectum & $11(19,3 \%)$ & $21(15,7 \%)$ \\
\hline Vese & $8(14 \%)$ & $12(9 \%)$ \\
\hline Bőr - melanoma malignum & $8(14 \%)$ & $10(7,5 \%)$ \\
\hline Emlö & $2(3,5 \%)$ & $7(5,2 \%)$ \\
\hline Tüdő & $3(5,3 \%)$ & $6(4,5 \%)$ \\
\hline Uterus & $1(1,8 \%)$ & $4(3 \%)$ \\
\hline Végtag & $4(7 \%)$ & $4(3 \%)$ \\
\hline Larynx & - & $3(2,2 \%)$ \\
\hline Parotis & - & $3(2,2 \%)$ \\
\hline Prosztata & $1(1,8 \%)$ & $2(1,5 \%)$ \\
\hline Pajzsmirigy & $1(1,8 \%)$ & $2(1,5 \%)$ \\
\hline Here & - & $2(1,5 \%)$ \\
\hline Maxilla & - & $1(0,7 \%)$ \\
\hline Garat & - & $1(0,7 \%)$ \\
\hline Hypopharynx & $2(3,5 \%)$ & $1(0,7 \%)$ \\
\hline Hematológiai & $1(1,8 \%)$ & $1(0,7 \%)$ \\
\hline Hepar & - & $1(0,7 \%)$ \\
\hline Nyelvgyök & - & $1(0,7 \%)$ \\
\hline Szem & - & $1(0,7 \%)$ \\
\hline Nyelőcső & $1(1,8 \%)$ & - \\
\hline Húgyhólyag & $1(1,8 \%)$ & - \\
\hline
\end{tabular}

2. táblázat A primer tumor kiindulási helye szerinti megoszlás azonos és/ vagy ellenoldali, ismételt metastasectomián átesett betegek között, vizsgált csoportonként lebontva

\begin{tabular}{lcc}
\hline A primer tumor helye & $\begin{array}{c}2006-2010 \\
(\mathrm{n}=3)\end{array}$ & $\begin{array}{c}2014-2018 \\
(\mathrm{n}=20)\end{array}$ \\
\hline Rectum & - & $5(3,7 \%)$ \\
Colon & $1(1,8 \%)$ & $4(3 \%)$ \\
Parotis & - & $3(2,2 \%)$ \\
Végtag & $2(3,5 \%)$ & - \\
Uterus & - & $2(1,5 \%)$ \\
Here & - & $1(0,7 \%)$ \\
Maxilla & - & $2(1,5 \%)$ \\
Vese & - & $1(0,7 \%)$ \\
Bőr - melanoma malignum & - & $1(0,7 \%)$ \\
Garat & - & $1(0,7 \%)$ \\
\hline
\end{tabular}

2006 és 2010 között 57 mütét történt, 49,1\%-ban (n = 28) bal oldalról, 49,1\%-ban $(\mathrm{n}=28)$ jobb oldalról, 1,8\%-ban $(\mathrm{n}=1)$ mindkét oldalról egy ülésben történt metastasectomia. Együléses kétoldali mütétnél mindkét oldalon posterolateralis thoracotomiát végeztünk. Szoli-
3. táblázat $\mid$ A mútéti típusok megoszlása vizsgálati csoportonként

\begin{tabular}{|c|c|c|}
\hline A mútét típusa & $\begin{array}{c}2006-2010 \\
(n=57)\end{array}$ & $\begin{array}{c}2014-2018 \\
(\mathrm{n}=134)\end{array}$ \\
\hline Atípusos reszekció & $22(38,6 \%)$ & $62(46,3 \%)$ \\
\hline Lobectomia & $18(31,6 \%)$ & $36(26,9 \%)$ \\
\hline Pulmonectomia & $6(10,5 \%)$ & $2(1,5 \%)$ \\
\hline Segmentectomia & $4(7 \%)$ & $13(9,7 \%)$ \\
\hline Bilobectomia & $1(1,8 \%)$ & $1(0,7 \%)$ \\
\hline Lobectomia + atípusos reszekció & $1(1,8 \%)$ & $6(4,5 \%)$ \\
\hline Lobectomia + segmentectomia & $1(1,8 \%)$ & $2(1,5 \%)$ \\
\hline Többszörös atípusos reszekció & $1(1,8 \%)$ & $3(2,2 \%)$ \\
\hline $\begin{array}{l}\text { Atípusos reszekció + rekeszizom- } \\
\text { reszekció }\end{array}$ & $2(3,5 \%)$ & - \\
\hline Atípusos reszekció + bordareszekció & $1(1,8 \%)$ & - \\
\hline Enucleatio & - & $2(1,5 \%)$ \\
\hline Bronchusreszekció & - & $1(0,7 \%)$ \\
\hline Lobectomia + rekeszizom-reszekció & - & $1(0,7 \%)$ \\
\hline Segmentectomia + atípusos reszekció & - & $4(3 \%)$ \\
\hline Atípusos reszekció + sternumreszekció & - & $1(0,7 \%)$ \\
\hline
\end{tabular}

ter elváltozást $54,4 \%$-ban $(\mathrm{n}=31)$, multiplex eltérést $45,6 \%$-ban $(\mathrm{n}=26)$ találtunk.

2014 és 2018 között 134 mütétet végeztünk, 52,2\%ban $(\mathrm{n}=70)$ bal oldalról, 44,8\%-ban $(\mathrm{n}=60)$ jobb oldalról végeztük a beavatkozást. $3 \%$-ban $(n=4)$ mindkét oldalról egy ülésben történt metastasectomia, ezen belül 2 betegnél sternotomiából, 2 betegnél együléses, kétoldali VATS-behatolásból. Szoliter tüdőáttétet 58,2\%-ban $(\mathrm{n}=78)$, multiplex áttétet $41,8 \%$-ban $(\mathrm{n}=56)$ észleltünk.

Az elvégzett mútétek megoszlását áttekintve azt találtuk, hogy a leggyakrabban végzett beavatkozás az atípusos gépi ékreszekció (38,6\% vs. 46,3\%) volt, ezt követte a lobectomia $(31,6 \%$ vs. $26,9 \%)$, majd a pulmonectomia $(10,5 \%$ vs. $1,5 \%)$ és a segmentectomia (7\% vs. $9,7 \%)$ (3. táblázat).

A mütéttechnikai megoldásokat vizsgálva az láthatjuk, hogy 2006 és 2010 között a mútétek 5,3\%-a $(\mathrm{n}=3)$ történt VATS-technikával, uniportalis VATS vagy VATS NITS mútét nem történt, míg a 2014 és 2018 közötti időszakban 64,9\%-ban ( $\mathrm{n}=87$ ) VATS mütét, 21 ,7\%-ban $(\mathrm{n}=29)$ uniportalis VATS, míg 10,4\%-ban $(\mathrm{n}=14)$ VATS NITS-metastasectomia történt.

A vizsgált időszakokban mediastinalis nyirokcsomóérintettséget 19,3\%-ban $(\mathrm{n}=11)$ és 9,7\%-ban $(\mathrm{n}=13)$ találtunk. Nyirokcsomó-pozitív esetekben a primer tumor origója szerinti, csoportonkénti megoszlás az összes beteget tekintve az alábbi volt: rectum: $n=3(5,3 \%)$, vese: $\mathrm{n}=2(3,5 \%)$, végtag: $\mathrm{n}=1(1,8 \%)$, pajzsmirigy: $\mathrm{n}=$ $1(1,8 \%)$, colon: $\mathrm{n}=1(1,8 \%)$, hematológiai: $\mathrm{n}=1$ $(1,8 \%)$, húgyhólyag: $\mathrm{n}=1(1,8 \%)$, bőr - melanoma 
malignum: $\mathrm{n}=1(1,8 \%)$, illetve colon: $\mathrm{n}=5(3,7 \%)$, vese: $\mathrm{n}=3(2,2 \%)$, emlő: $\mathrm{n}=2(1,5 \%)$, végtag: $\mathrm{n}=1(0,7 \%)$, rectum: $\mathrm{n}=\mathrm{l}(0,7 \%)$, bőr - melanoma malignum: $\mathrm{n}=\mathrm{l}$ $(0,7 \%)$.

Két- vagy többüléses, ismételt metastasectomiáknál az első periódusban mindhárom esetben ellenoldali metastasis került eltávolításra, ezen betegeknél a metastasectomiák között eltelt idő átlagosan 7,33 hónap (1-20 hó) volt. A második periódusban 4 esetben azonos oldali, 16 esetben ellenoldali ismételt metastasectomia történt, itt a metastasectomiák között eltelt időszak átlagosan 6 hónap (1-31 hó) volt.

A primer tumor és a tüdőáttét eltávolítása közötti betegségmentes időszak az első periódusban átlagosan 45,2 hónap (0-168 hó), szoliter metastasis esetén 55,4 hónap (0-168 hó), multiplex áttéteknél 30,9 hónap (0144 hó), míg a második periódusban átlagosan 33,8 hónap (0-180 hó), szoliter metastasis esetén 39,3 hónap (0-174 hó), multiplex áttéteknél 25,8 hónap (0-180 hó) volt.

Az 1. csoportban észlelt 39 hónapos medián túlélés a második csoportban 59 hónapra emelkedett. Az ötéves túlélés mindkét csoportban $41 \%$ volt, így szignifikáns különbséget nem tudtunk igazolni $(\mathrm{p}=0,282)$.

\section{Megbeszélés}

Az első tüdőmetastasis-eltávolítást Weinlechner végezte 1882-ben [5]. Számítógépes adatrögzítésünk 1995-ös kezdete óta hasonlóan emelkedő tendenciát észlelünk. A tüdő az egyik leggyakoribb célszerv metastasisok képzése szempontjából, melyek a leggyakrabban a vénás elvezetésnek megfelelően hematogén terjedés útján alakulhatnak ki. Ezt követi a nyirokúton át történő anterográd vagy retrográd terjedés. A metastasisok lehetnek szoliterek vagy multiplexek. A különböző metastasismegjelenési formák között fontos különbséget tenni, mert jelentősen eltér a diagnosztika, a kezelés és a prognózis is [6]. Colorectalis daganatok esetén a diagnózis időpontjában a betegek kb. 20\%-ának van áttéti daganata, köztük máj- vagy tüdőmetastasisa [7], ezek együttes előfordulása 5-10\%-ra tehető [5]. Colon- és rectumtumorok esetén arányaiban eltérő metastasis-lokalizációval találkozhatunk: míg colontumorok esetén a májmetastasisok gyakrabban fordulnak elő, addig rectumtumorok esetén a tüdőmetastasisok incidenciája magasabb [7]. Osteosarcoma esetén a betegek $81 \%$-ának van tüdőmetastasisa a diagnóziskor [8]. A bőrből kiinduló melanomás betegek 80\%-ának van áttétes daganata, 40\%-nak csak szoliter tüdőmetastasisa van [9].

Metastasis miatti tüdőreszekció az alábbi kritériumok esetén végezhető: a primer tumor kontrollált állapotban van, technikailag eltávolítható metastasis, jó általános állapot és funkcionális kapacitás, nincs extrathoracalis metastasis - kivétel például a reszekábilis májmetastasis [10]. A tüdőből végzett metastasis-eltávolítások az egyes európai mellkassebészeti munkacsoportok beavatkozása- inak 15-50\%-át teszik ki [11]. Egyoldali érintettség esetén az anterior, az axillaris és a posterolateralis thoracotomia mellett VATS-technikával végzett bevatkozás is választható, míg kétoldali metastasisoknál akár a sternotomia és a 'clamshell' feltárás [5], de a subxiphoid és a transcervicalis feltárás is eredményes lehet. Legkorábbi esetünknél 2 oldali thoracotomiából, majd medián sternotomiából, illetve 2 oldali VATS-feltárásból végeztük az együléses kétoldali reszekciókat.

A primer tumor kiindulási helyétől függően szükséges lehet a mediastinalis és hilaris nyirokcsomó-blokkdissectio vagy nyirokcsomó-mintavétel ('sampling'). Tüdőeredetû metastasis esetén az azonos oldali nyirokcsomóblokkdissectio már a primer mútétnél elvégzésre kerül. Az ellenoldali tüdőben lévő áttét esetén ellenoldali hilaris és mediastinalis blokkdissectio is szükséges. Amennyiben a primer tumornak és az áttétnek nincs a sebészeti eltávolításon kívül adekvát kezelési alternatívája (például sarcomák), úgy indokolt a szisztémás mediastinalis és hilaris nyiromcsomó-blokkdissectio. Egyéb esetekben nincs evidencia a tüdőmetastasisok esetén történő mediastinalis nyirokcsomó-eltávolításra, azonban minden esetben van prognosztikai jelentősége. Azokban az esetekben, amikor a beteg tumormentessé válik a tüdőmetastasis reszekciója és a hilaris, valamint mediastinalis nyirokcsomó-blokkdissectio által - R0-reszekció -, mindenképp javasolt a nyirokcsomók eltávolítása is. CRC esetén az N1-es és N2-es nyirokcsomó-régiókra kiterjedő blokkdissectio vagy 'sampling' a betegség esetleges disszeminációjának fokáról ad felvilágosítást, de terápiás hatása nincs alátámasztva [5]. Betegeinknél a medián túlélés a nyirokcsomó-pozitív esetekben 33 hónap, míg a nyirokcsomó-negatív esetekben 39,3 hónap volt. Ezen értékek az első időszakban 54,8 hónap vs. 59,6 hónap, míg a második időszakban 14,9 hónap vs. 30,5 hónap voltak.

Sarcomák és CRC esetén rossz prognosztikai tényezőnek számít a rövid DFI, a többszörös tüdőmetastasisok jelenléte, ami a CRC esetében kiegészül az emelkedett preoperatív CEA-szinttel és mediastinalis nyirokcsomóáttéttel, míg a korábbi, májban lévő CRC-metastasis reszekciója nem befolyásolja a túlélést $[5,11-13]$. CRC tüdőáttéte esetén a mellkasi nyirokcsomók érintettsége 7,1\% és 30,3\% közé esik, míg ezt sarcomák esetén 20,3\%nak, illetve vesesejtes tumor esetén 42,2\%-nak találták [5]. Betegeink között 19,3\%-ban, illetve 9,7\%-ban találtunk mediastinalis nyirokcsomó-érintettséget a vizsgált időszakokban, csoportonként.

A két vizsgált periódusunk alatt több mint megduplázódott a tüdőmetastasis indikációjával végzett mútétek száma $(\mathrm{n}=57$ vs. $\mathrm{n}=134)$. A primer tumor megoszlásában nem találtunk jelentős eltérést. A mútéttechnikai megoldásokat áttekintve a pulmonectomiák számának jelentős csökkenését (10,5\% vs. 1,5\%), míg a segmentectomiák számának növekedését (7\% vs. 9,7\%) láthatjuk.

A primer tumoros folyamat és a tüdőáttét mütéte között eltelt betegségmentes időszak hossza az első csoportban észlelt átlagos 45,2 hónapról 33,82 hónapra 
csökkent. Úgy gondoljuk, ebben jelentős szerepe van a rendszeres és folyamatosan javuló onkológiai gondozásnak és a javuló diagnosztikus lehetőségeknek, ami lehetővé teszi a tüdőáttétek minél korábbi diagnózisát és kezelését. A DFI az alapbetegségtől függően széles spektrumon mozoghat. Schmid és mtsai csont- és lágyrész-sarcomák esetén 14,7 hónapos DFI-t találtak [14], míg Pfannschmidt és mtsai átfogó vizsgálatukban colorectalis tumorok esetén 20 és 37,5 hónap közötti DFIértéket kaptak [5]. Eseteinkben a végtagi csont- és lágyrész-sarcomák miatt metastasectomián átesett betegeknél 17,9 hónap, míg colorectalis tumorok esetén 33,6 hónap betegségmentes periódust találtunk a primer tumor és a metastasis mütéte között.

Az ismételt, két vagy többüléses metastasectomia aránya az első periódusban 5,6\%, míg a második periódusban $17,5 \%$ volt. Egyik betegünkön a legtöbbször, 4 alkalommal végeztünk metastasectomiát. Petersen és mtsai melanoma malignum kapcsán végzett ismételt, két- vagy többüléses, azonos vagy ellenoldali metastasectomia esetén találtak átlagosan 9 hónap betegségmentes túlélést a mưtétek között [9]. Betegeinknél ez átlagosan 7,3 hónap és 6 hónap volt csoportonként. Nem csökkentette szignifikánsan a túlélést a többüléses metastasectomia az együléses metastasectomiával szemben ( 15 hónap vs. 17 hónap) [9], sőt egyes szerzők szerint még növelheti is azt [15].

Tüdőmetastasisok esetén is mindig a beteg általános teherebíró képességéhez, az optimális terápiás lehetőséghez egyénre szabottan kell megállapítani a kezelési sémát. A sebészi reszekció mellett szóba jöhet kemoterápia, radioterápia, immunterápia, biológiai terápia, lézerkezelés, 'ligasure', 'ultracision', thermoablativ terápia $[5,8,11,12,16]$.

Minimálinvazív módszerrel javasolt a metastasectomia, ha a primer tumor colorectalis vagy vesesejtes eredetü - ezek általában 1-2 nagyobb nodulus formájában jelentkeznek, szemben a sarcomákkal, melyek több és apróbb áttétet adnak - [17]; ha az áttét $3 \mathrm{~cm}$ vagy annál nagyobb átmérőjü, a periférás tüdőterületen helyezkedik el, valamint az ellenoldalon nincs a tüdőben metastasis [15]. A vizsgált időszakok alatt jelentősen emelkedett a VATS-metastasectomia aránya gyakorlatunkban $(5,3 \%$ vs. $64,9 \%)$. Ez megfelel a magyar, országos statisztikának, mely szerint 2008-ban a 200 metastasectomiából 15-öt $(7,5 \%)$ végeztek VATS-technikával [18], 2013ban 316 mütétből 107 volt a VATS-módszerrel (33,9\%) végzett tüdőáttét-eltávolítás [3]. A diagnosztikus és lokalizációs technikák fejlődésével a VATS-módszerrel végzett kis méretű elváltozások eltávolítására is lehetőség nyílt [19], eredményei megegyeznek a nyitott mütétek eredményeivel [20]. A nem tapintható vagy kis méretú intrapulmonalis elváltozások jelölésére több technika is használható, mint a drót- vagy izotópjelölés [19], metilénkékkel történő festékjelölés, ENB, intraoperatív ultrahang [21]. Jelenleg intraoperatív mellkasi CT-vizsgálat - hibrid mütői lehetőségünk nincs az ilyen jellegű elvál- tozások pontos lokalizálására. A torakoszkópos mútéti technikával végzett metastasectomiák számának növekedésében jelentős szerepe van a nagy felbontású, vékony szeletes mellkasi CT-vizsgálatnak. Kang és mstai tanulmányában a nem osteosarcoma tüdőmetastasisa miatt készített 1 mm-es szeletvastagságú, 16 csatornás, multidetektoros CT-vizsgálat 96\%-os szenzitivitást talált. Ugyanezen vizsgálat az $5 \mathrm{~mm}$-nél nagyobb elváltozásoknál szelektált csoportokban 100\%-os szenzitivitást mutatott [22]. Így a korábban csak a kis méretű tüdőáttétek tapintással történő lokalizációja céljából [5] végzett thoracotomiás beavatkozás javallata [23] kezd háttérbe szorulni.

Amennyiben a preoperatív CT-vizsgálaton látott elváltozást nem találjuk VATS során, vagy bármilyen, a torakoszkópia vagy egyéb technikai ok miatti hátrány okán nem tudjuk elvégezni a reszekciót, úgy Mutsaerts és mtsai konverziót javasolnak thoracotomiára; beteganyagukban 20\% körüli konverziós rátát találtak [15].

A metastasectomiát követően a betegek rendszeres onkológiai kontrollvizsgálaton vesznek részt, mely a primer tumornak megfelelő protokoll szerint történik. Az 5 éves túlélés széles spektrumon mozoghat annak függvényében, hogy mi volt az alapbetegség. A legjobb eredmények csírasejtes tumor esetén láthatók (68\%), míg a legrosszabbak a melanoma metastasisainál (21\%) [11]. Az utóbbi eseteiben a metastasectomia az 5 éves túlélést 3-5\%-ról 21\%-ra emelheti [9]. CRC esetén az 5 éves túlélés metastasectomia után $50 \%$ körüli, míg a nem kezelt esetekben $5 \%$ alatti $[5,13]$. Osteosarcoma esetén az 5 éves túlélés 20-25\%, lágyrész-sarcoma esetén 13-15\% közötti [8]. Az 5 éves, a primer tumor kiindulási helyétől független túlélés mindkét csoportunkban $41 \%$ volt (1. ábra).

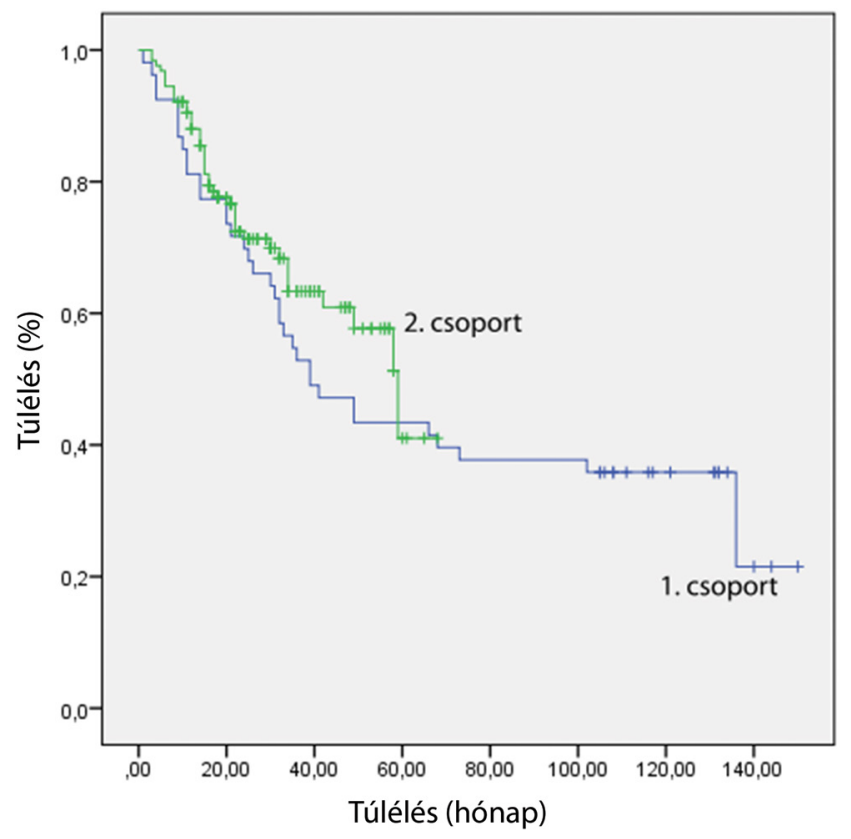

1. ábra $\mid$ A túlélés megoszlása mindkét vizsgált csoportban 


\section{Következtetés}

Egyéni mérlegelést követően szoliter vagy multiplex metastasis esetén a pulmonalis metastasectomia a beteg számára a legoptimálisabb terápiás megoldás lehet. Figyelembe véve a primer tumor természetét, az áttétek számát, egyéb hatásos kezelési lehetőségeket, a beteg mưtéti teherbíró képességét, azt láthatjuk, hogy a lehetőség szerint minimálinvazív megoldással végzett, parenchymakímélő - akár többszöri - tüdőreszekció a beteg hosszú távú betegségmentes túlélését is eredményezheti.

Anyagi támogatás: A közlemény megírása és a kutatómunka anyagi támogatásban nem részesült.

Szerzői munkamegosztás: N. T.: Adatgyüjtés, elemzés, a cikk megírása. F. J.: Témavezető, kritikai megjegyzések, a kézirat végleges megszövegezése. L. Gy.: Kritikai megjegyzések. Sz. Zs., P. B., B. Zs. V.: Kutatás, kritikai megjegyzések. T. L., M. A.: Kritikai megjegyzések. Z. T.: Adatgyưjtés, kritikai megjegyzések. A cikk végleges változatát valamennyi szerző elolvasta és jóváhagyta.

Érdekeltségek: A szerzőknek nincsenek érdekeltségeik.

\section{Irodalom}

[1] Seyfried NT, Huysentruyt LC. On the origin of cancer metastasis. Crit Rev Oncog. 2013; 18: 43-73.

[2] Czeyda-Pommersheim F, Kovács T, Sulyok Z, et al. Change of attitude in the surgical treatment of lung metastases. [Szemléletünk alakulása a tüdőáttétek sebészi kezelésében.] Magy Seb. 2004; 57: 336-342. [Hungarian]

[3] Bulletin of Korányi 2014. The epidemiological and operational data of the pulmonology network in 2013. [A pulmonológiai hálózat 2013. évi epidemiológiai és múködési adatai.] Korányi Bulletin 2014; (1): 4-37. Available from: https://www.koranyi. hu/tartalom/bulletin/Evkonyv2014.pdf [accessed: October 17, 2019]. [Hungarian]

[4] European Society of Thoracic Surgeons, Database Committee. Silver Book 2015. Database annual report. ESTS, Exeter. Available from: http://www.ests.org/_userfiles/pages/files/ ESTS\%20201Silver_Book_FULL_PEF.pdf [accessed: October $17,2019]$.

[5] Pfannschmidt J, Dienemann H, Hoffmann H. Surgical resection of pulmonary metastases from colorectal cancer: a systematic review of published series. Ann Thorac Surg. 2007; 84: $324-338$.

[6] Reyes KD, Pienta JP. The biology and treatment of oligometastatic cancer. Oncotarget 2015; 6: 8491-8524.

[7] Qiu M, Hu J, Yang D, et al. Pattern of distant metastases in colorectal cancer: a SEER based study. Oncotarget 2015; 6: 38658-38666.

[8] Treasure T, Fiorentino F, Scarci M, et al. Pulmonary metastasectomy for sarcoma: a systematic review of reported outcomes in the context of Thames Cancer Registry data. BMJ Open 2012; 2: $\mathrm{e} 001736$.

[9] Petersen RP, Hanish SI, Haney JC, et al. Improved survival with pulmonary metastasectomy: an analysis of 1720 patients with pulmonary metastatic melanoma. J Thorac Cardiovasc Surg. 2007; 133: 104-110.

[10] Pfannschmidt J, Hoffmann H, Dienemann H. Reported outcome factors for pulmonary resection in metastatic colorectal cancer. J Thorac Oncol. 2010; 5(6 Suppl 2): S172-S178.

[11] Treasure T, Milošević M, Fiorentino F, et al. Pulmonary metastasectomy: what is the practice and where is the evidence for effectiveness? Thorax 2014; 69: 946-949.

[12] Gonzalez M, Poncet A, Combescure C, et al. Risk factors for survival after lung metastasectomy in colorectal cancer patients: a systematic review and meta-analysis. Ann Surg Oncol. 2013; 20: 572-579.

[13] Fiorentino F, Hunt I, Teoh K, et al. Pulmonary metastasectomy in colorectal cancer: a systematic review and quantitative synthesis. J R Soc Med. 2010; 103: 60-66.

[14] Schmid S, Le UT, Zeisel C, et al. Pulmonary metastasectomy in sarcoma-experiences with laser-assisted resection. J Thorac Dis. 2018; 10: 314-320.

[15] Mutsaerts EL, Zoetmulder FA, Meijer S, et al. Long term survival of thoracoscopic metastasectomy vs metastasectomy by thoracotomy in patients with a solitary pulmonary lesion. Eur J Surg Oncol. 2002; 28: 864-868.

[16] Venuta F, Rolle A, Anile M, et al. Techniques used in lung metastasectomy. J Thorac Oncol. 2010; 5(6 Suppl 2): S145-S150.

[17] Rusch VW. Surgical techniques for pulmonary metastasectomy. Semin Thorac Cardiovasc Surg. 2002; 14: 4-9.

[18] Bulletin of Korányi 2009. The epidemiological and operational data of the pulmonology network in 2008. [A pulmonológiai hálózat 2008. évi epidemiológiai és múködési adatai.] Korányi Bulletin 2009; (1): 1-68. Available from: https://www. koranyi.hu/tartalom/bulletin/Evkonyv2009.pdf [accessed: October 19, 2019]. [Hungarian]

[19] Farkas A, Kocsis Á, Andi J, et al. Minimally invasive resection of nonpalpable pulmonary nodules after wire- and isotope-guided localization. [Nem tapintható tüdőgócok drót- és izotópjelölés segítségével történő minimálinvazív mútéti eltávolítása.] Orv Hetil. 2018; 159: 1399-1404. [Hungarian]

[20] Meng D, Fu L, Wang L, et al. Video-assisted thoracoscopic surgery versus open thoracotomy in pulmonary metastasectomy: a meta-analysis of observational studies. Interact Cardiovasc Thorac Surg. 2016; 22: 200-206.

[21] Lin MW, Chen SJ. Image-guided techniques for localizing pulmonary nodules in thoracoscopic surgery. J Thorac Dis. 2016; 8(Suppl. 9): S749-S755.

[22] Kang MC, Kang CH, Lee HJ, et al. Accuracy of 16-channel multi-detector row chest computed tomography with thin sections in the detection of metastatic pulmonary nodules. Eur J Cardiothorac Surg. 2008; 33: 473-479.

[23] Svastics E, Troján I. Surgery for lung metastases. [A tüdőmetasztázisok sebészete.] Orv Hetil. 1996; 137: 2671-2674. [Hungarian]

(Németh Tibor dr., Szeged, Semmelweis u. 8., 6720 e-mail: nemethsurg@gmail.com)

A cikk a Creative Commons Attribution 4.0 International License (https://creativecommons.org/licenses/by/4.0/) feltételei szerint publikált Open Access közlemény melynek szellemében a cikk bármilyen médiumban szabadon felhasználható, megosztható és újraközölhető, feltéve, hogy az eredeti szerző és a közlés helye, illetve a CC License linkje és az esetlegesen végrehajtott módosítások feltüntetésre kerülnek. (SID_1) 